\title{
Taphonomy of the earliest Cambrian linguliform brachiopods
}

Angela Forchielli, Michael Steiner, Shixue Hu, Carsten Lüter, and Helmut Keupp

Acta Palaeontologica Polonica 59 (1), 2014: 185-207 doi: http://dx.doi.org/10.4202/app.2011.0182

The Early Cambrian Burgess Shale-type fossil Lagerstätten of Yunnan Province (Chengjiang; Guanshan) are crucial in understanding the Cambrian bioradiation. Brachiopods are applied here as a critical model phylum to analyze the taphonomy of Yunnan fossil Lagerstätten, because shell and tissue composition of modern brachiopods can be compared with exceptionally preserved Cambrian remains. Systematic elemental mapping and energy-dispersive $\mathrm{X}$-ray analyses have been carried out to study fossil brachiopods and their matrix from Cambrian Stages 3-4 and modern linguliform brachiopods from several geographical regions in order to evaluate the detailed structure of the shells and the biological and environmental influences on shell composition. Analyses of earliest Cambrian fossils encompassing the complete spectrum of weathering stages show a primary organo-phosphatic brachiopod shell, visible in unweathered specimens, and a successive dissolution and replacement of the shell during weathering, observable in specimens that underwent different stages of weathering. Therefore, our study reveals that earliest Cambrian linguliform brachiopods from the Chengjiang and Guanshan Biotas developed organo-phosphatic shells as their Recent counterparts. Early carbon and apatite preservation together with rapid deposition in claystone, instead of early iron adsorption, appears crucial for the preservation of highly delicate tissue. Primary calcium, phosphorus, organic carbon, and a multilayered shell are present, by inference between Cambrian fossils and Recent specimens, through the whole Phanerozoic. Elements such as silicon, sulphur, calcium, phosphorus, and iron were detected, impregnated with organic compounds in some organs of modern Lingula, and related to the potential of fossilization of Cambrian linguliform brachiopods. Ferromanganese precipitates traced in the shell of in vivo specimens of modern Lingula may enhance the potential for fossilization too.

Key words: Linguliformea, Brachiopoda, Chengjiang Fauna, Guanshan Fauna, taphonomy, elemental mapping, Cambrian, China.

Angela Forchielli [geoange@ hotmail.it], Michael Steiner [michael.steiner@fu-berlin.de ], and Helmut Keupp [keupp@zedat.fu-berlin.de], Freie Universität Berlin, Malteserstraße 74-100, Haus D, 12249 Berlin, Germany; Shixue Hu [hushixue@ hotmail.com ], Chengdu Institute of Geology and Mineral Resources, 610081 Chengdu, China; Carsten Lüter [carsten.lueter@mfn-berlin.de], Museum für Naturkunde Leibniz-Institut für Evolutions- und Biodiversitätsforschung an der Humboldt-Universität zu Berlin, Invalidenstraße 43, 
10115 Berlin, Germany.

This is an open-access article distributed under the terms of the Creative Commons Attribution License (for details please see creativecommons.org), which permits unrestricted use, distribution, and reproduction in any medium, provided the original author and source are credited.

FoF 